Article

\title{
Preliminary Thermal Investigations of Calcium Antimonate Opacified White Glass Tesserae
}

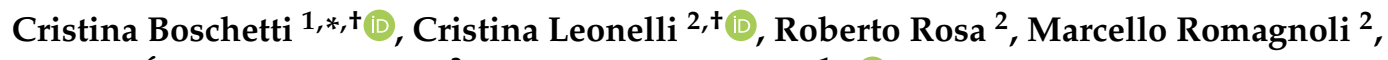 \\ Miguel Ángel Valero Tévar ${ }^{3}$ and Nadine Schibille ${ }^{1, *}$ (i) \\ 1 IRAMAT-CEB, UMR5060, CNRS/Université d'Orléans, 3D rue de la Férollerie, CS 60061, \\ 45071 Orléans CEDEX 2, France \\ 2 Dipartimento di Ingegneria "Enzo Ferrari", Università degli Studi di Modena e Reggio Emilia, Via Pietro \\ Vivarelli 10, 41125 Modena, Italy; cristina.leonelli@unimore.it (C.L.); roberto.rosa@unimore.it (R.R.); \\ marcello.romagnoli@unimore.it (M.R.) \\ 3 Departamento de Historia Antigua, Facultad de Humanidades y Ciencias de la Educación, Universidad de \\ Castilla-La Mancha, Av. de los Altares s/n, 16071 Cuenca, Spain; MiguelAngel.Valero@uclm.es \\ * Correspondence: cristina.boschetti@cnrs-orleans.fr (C.B.); nadine.schibille@cnrs-orleans.fr (N.S.) \\ + These authors contributed equally to this work.
}

Received: 11 May 2020; Accepted: 24 June 2020; Published: 26 June 2020

\begin{abstract}
Calcium antimonate (in the hexagonal or cubic form) dispersed in the glass matrix is an artificially synthesized phase commonly documented as opacifier for white glasses during the Roman period. Glasses of this type occasionally contain variable amounts of lead oxide. There is no consensus about the origin and role of the lead component in white glasses, whether it was functional to modify the workability of the glass and/or to help the precipitation of the particles, or whether it was an unintentional pollutant introduced with the raw materials. A group of lead and lead-free white mosaic tesserae from the fourth-century CE villa of Noheda in Spain were analyzed by differential scanning calorimetry (DSC) and high temperature X-ray diffraction (HTXRD) to evaluate the impact of variable amounts of lead oxide in the precipitation of calcium antimonate on the viscosity of the glass. The analyzed glasses show thermal events that have been related to the composition of the glass via multicomponent linear regression model. $\mathrm{CaSb}_{2} \mathrm{O}_{6}$ and $\mathrm{Ca}_{2} \mathrm{Sb}_{2} \mathrm{O}_{7}$ formed in the glass during the cooling phase and the glass was not reheated. Lead oxide influences the thermal behavior of the glass, lowering the onset temperatures of all the events, implying a more cost-effective production process. We propose that lead was added intentionally or that lead-bearing raw materials were selected specifically by the ancient glass artisans.
\end{abstract}

Keywords: calcium antimonate; Roman glass technology; glass opacification; DSC; high temperature XRD

\section{Introduction}

Opacity of glass implies either the addition of mineral pigments to the base glass or the in situ precipitation of crystals during the thermal cycle. Calcium antimonate, a synthetized pigment which does not exist in nature, is attested in the form of hexagonal $\left(\mathrm{CaSb}_{2} \mathrm{O}_{6}\right)$ or cubic $\left(\mathrm{Ca}_{2} \mathrm{Sb}_{2} \mathrm{O}_{7}\right)$ crystals to generate opaque white glass. The use of antimony as opacifier is documented since the very beginnings of glass making in the Late Bronze Age, both in Mesopotamia as well as in Egypt [1-3]. Calcium antimonate was used not exclusively for making white glass, but in combination with strongly coloured glasses; it also achieves a number of cool shades, for instance blue, aqua-green, turquoise, grey, and light purple. During the same period, lead antimonate $\left(\mathrm{Pb}_{2} \mathrm{Sb}_{2} \mathrm{O}_{7}\right)$ served to produce opaque yellow and shades of green [1-3]. Unlike calcium antimonate, lead antimonate occurs in nature as bindheimeite 
$\left(\mathrm{Pb}_{2} \mathrm{Sb}_{2} \mathrm{O}_{6}[\mathrm{O}, \mathrm{OH}]\right)$ and was probably used by glass artisans both in its mineral and in its synthetized form $[4,5]$. The appearance of both calcium antimonate and lead antimonate as pigments seem to be related to the origins of glass making. No use of either calcium or lead antimonate prior to the invention of vitreous materials has been reported [1]. Calcium antimonate-based pigments continued to be used as opacifiers during the Hellenistic and the Roman period, and have been discussed in the literature particularly in connection with Hellenistic mosaic tesserae and vessels [6,7], as well as Roman mosaic tesserae [8-19] and opus sectile panels [20,21]. For reasons not well understood, the use of calcium antimonate as an opacifying agent for glass ceased towards the end of the Western Roman Empire, when it was replaced by calcium stannate [22]. Mosaic tesserae opacified by calcium antimonate can still be found during the Early Middle Ages in the Italian Peninsula, but these incidents are likely to represent the reuse of older Roman tesserae rather than the continued use of calcium antimonate $[17,23]$. In the eastern Mediterranean, the transition to a tin-based opacification seems to have been a much faster process [22]. Alongside the use of calcium stannate, eastern Mediterranean glasses are occasionally opacified by calcium phosphate from the fifth century onwards ([24] and references therein). Antimony white re-appears in the Islamic world in connection with Egypt 2 natron-type glass in the ninth century for a short period and then only as patches on some Islamic glass weights [25]. This isolated re-appearance is difficult to explain because, at present, calcium antimonate has not been documented in other contemporary productions. In contrast, investigations conducted on glazed pottery revealed a revival of lead antimonate in ninth-tenth century Egypt [26]. In the fifteenth century, calcium antimonate re-surfaces in context of glass technologies. It is mentioned as the white opacifier of choice in Venetian glass recipe books [27], while lead antimonate is listed as yellow pigment for glazes in a number of Italian treatises on ceramics [28]. From the sixteenth century, lead antimonate was a popular pictorial pigment, known as Naples Yellow, while calcium antimonate remains confined to the realm of glass opacification [28].

Interestingly, calcium antimonate-opacified glasses are often quite atypical in terms of their composition, because they sometimes have unusually high lead oxide concentrations. Elevated lead oxide occurs as early as the Hellenistic period and examples are documented throughout the Roman Period [9,27-31]. In glasses where antimony acts as a decolourant, lead oxide contents were found to gradually decrease from the late Hellenistic period through to the second century $\mathrm{CE}$, when high lead contents finally disappeared [32]. The role of elevated lead oxide concentrations in these glasses has triggered a major debate, especially in relation to the forming technology of cameo glass. Cameo glass is a complex working technique used for vessels and decorative plaques [33], where a core of usually translucent blue or purple glass is covered with a layer of opaque white glass, which is subsequently cold-carved to create a low-relief decoration. It has been argued that the elevated lead oxide contents served to lower the viscosity and the hardness of the glass [29]. In the cameo-glass technology the use of a softer glass for the external white layer can be advantageous in different ways. Firstly, in order to achieve a good final result, the white layer has to be perfectly homogeneous. A glass with a high viscosity is more likely to trap air bubbles, which can potentially compromise the low-relief decoration. At the same time, glass containing lead is softer and easier to carve. Lead-white glass often underlies Migration period beads opacified by calcium stannate and formed by winding [34]. The winding technique involves the manipulation of a gob of hot glass around an iron rod, the mandrel. A glass with a lower viscosity can be advantageous for this operation, because it allows working at a lower temperature. Hence, elevated lead contents have been frequently interpreted as an intentional additive, instrumental in secondary working processes [34]. In contrast, some scholars attributed lead in white glasses to impurities in the raw materials and consider its presence accidental [35].

If the intentional addition of lead or the intentional selection of lead-bearing raw materials for the production of cameo glass or wound beads can be justified due to improved working properties, the presence of lead in mosaic tesserae is more difficult to explain, because the addition of lead would not bring any advantage in terms of glass-forming techniques. In case of tesserae, lead oxide may have instead benefited the optical properties, homogeneity and brilliance of the glass. The formation 
of calcium antimonate in natron glasses has been experimentally reproduced in the laboratory and it was found that the crystals were formed by in situ crystallisation after antimony oxide $\left(\mathrm{as} \mathrm{Sb}_{2} \mathrm{O}_{4}\right.$ or $\mathrm{Sb}_{2} \mathrm{O}_{5}$ ) was added to a base glass [14,36]. A long thermal cycle of $20 \mathrm{~h}$ at approximately $1100{ }^{\circ} \mathrm{C}$ has produced a result very close to the texture of Roman glasses. Experimental reproductions of calcium antimonate-opacified glasses have furthermore shown that lead oxide has an influence in the precipitation of the crystals [32]. Although these experimental studies offer a valuable approximation of how Roman and medieval opaque white glasses may have been generated, the effects have never been investigated directly in archaeological glass samples. In order to explore the role of lead oxide in the precipitation process of hexagonal $\left(\mathrm{CaSb}_{2} \mathrm{O}_{6}\right)$ and orthorhombic $\left(\mathrm{Ca}_{2} \mathrm{Sb}_{2} \mathrm{O}_{7}\right)$ forms of calcium antimonate, we compared the thermal behaviour with the crystalline phases in mosaic tesserae with different concentrations of lead oxide. This paper thus presents new insights into the production of Roman antimony white tesserae, and a potential explanation for their elevated lead contents adopting an in situ high temperature X-ray diffraction.

\section{Materials and Methods}

Ten white tesserae containing antimony from the extensive floor mosaic of the fourth-century villa of Noheda (Cuenca, Spain) were selected based on their varying levels of magnesium and lead oxide previously determined by LA-ICP-MS (Table 1, Table S1). This case study was selected to represent the opacification technology commonly attested in the Roman Empire. The full chemical composition, microtextural analysis and the values obtained for the certified glass standards were previously published [37]. The tesserae were freshly fractured and fragments of non-weathered glass were finely hand ground in an agate mortar (grain size less than 20 micrometre). The thermal behaviour of the samples was investigated by non-isothermal differential scanning calorimetry (DSC, Netzsch, Selb, Germany, model DSC 404). The measurements were performed on the finely powdered samples between room temperature and $1200{ }^{\circ} \mathrm{C}$, with heating rates of $10{ }^{\circ} \mathrm{C} / \mathrm{min}$ in static air. All DSC measurements were carried out on approximately 20.0-25.0 mg samples against an empty Pt-Rh crucible. Being aware that the finesse of the powder affects the thermal events, we carefully ground all the specimens to achieve the same final grain size [38].

Multicomponent Liner Regression (MLR) was adopted to probe the variations of independent variables (oxides content in $\mathrm{wt} \%$ ) on the dependent variables (Tg) with the aim to determine which one has a significant impact. According to the relationship between the dataset, a straight-line regression was used [39].

X-ray diffraction was conducted on the finely powdered glass and frontally loaded on a $\mathrm{Si}$ sample holder. X-ray diffraction patterns were acquired by the X'PERT PRO Panalytical diffractometer (Panalytical, Almelo, Netherlands) equipped with a real-time multiple strip detector $X^{\prime}$ Celerator with the following experimental settings: Ni filtered $\mathrm{Cu} K \alpha$ radiation $(\lambda=1.5418 \AA$ ); voltage $40 \mathrm{kV}$; tube current $40 \mathrm{~mA}$; divergence and anti-scatter slits $0.5^{\circ} ; 1 / 2^{\circ}$ divergence and receiving slits, incident beam with Soller $0.04 \mathrm{rad}$, mask fixed at $10 \mathrm{~mm}$, and step scan of $0.0167113^{\circ} 2 \theta$, angular range $10^{\circ}<2 \theta<60^{\circ}$. The application software version was X'Pert Date collector. 
Table 1. Major and minor elements of the 10 white tesserae from Noheda analysed by LA-ICP-MS (wt $\%$ ) [37] and temperatures $\left({ }^{\circ} \mathrm{C}\right)$ of the three endothermic peaks observed by DSC analysis (DSC peak temperature $\pm 2{ }^{\circ} \mathrm{C}$, due to peak maximum identification).

\begin{tabular}{|c|c|c|c|c|c|c|c|c|c|c|c|c|c|c|c|c|c|}
\hline Sample & $\mathrm{Na}_{2} \mathrm{O}$ & $\mathrm{MgO}$ & $\mathrm{Al}_{2} \mathrm{O}_{3}$ & $\mathrm{SiO}_{2}$ & $\mathrm{P}_{2} \mathrm{O}_{5}$ & $\mathrm{Cl}$ & $\mathrm{K}_{2} \mathrm{O}$ & $\mathrm{CaO}$ & $\mathrm{TiO}_{2}$ & $\mathrm{MnO}$ & $\mathrm{Fe}_{2} \mathrm{O}_{3}$ & $\mathrm{CuO}$ & $\mathrm{Sb}_{2} \mathrm{O}_{3}$ & $\mathrm{PbO}$ & $\begin{array}{l}\text { First } \\
\text { Peak } \\
(\mathrm{Tg})\end{array}$ & $\begin{array}{l}\text { Second } \\
\text { Peak } \\
\text { (Tg) }\end{array}$ & $\begin{array}{l}\text { Third } \\
\text { Peak } \\
(\mathrm{Tm})\end{array}$ \\
\hline Noheda 071 & 15.8 & 3.09 & 1.97 & 66.1 & 0.03 & 0.85 & 0.44 & 6.13 & 0.07 & 0.03 & 0.44 & 0.00 & 4.80 & 0.02 & 545 & 619 & - \\
\hline Noheda 076 & 14.7 & 4.03 & 1.68 & 62.7 & 0.02 & 0.90 & 0.43 & 6.71 & 0.06 & 0.01 & 0.34 & 0.00 & 8.09 & 0.16 & 539 & - & - \\
\hline Noheda 077 & 13.3 & 0.35 & 2.48 & 66.8 & 0.10 & 0.84 & 0.34 & 6.76 & 0.05 & 0.03 & 0.31 & 0.00 & 7.10 & 1.43 & 553 & 620 & 1154 \\
\hline Noheda 080 & 16.8 & 0.40 & 1.96 & 65.5 & 0.02 & 1.10 & 0.49 & 5.43 & 0.08 & 0.10 & 0.43 & 0.01 & 5.06 & 2.47 & 522 & 609 & 1132 \\
\hline Noheda 084 & 15.9 & 3.62 & 1.90 & 63.9 & 0.04 & 0.68 & 0.46 & 6.89 & 0.08 & 0.02 & 0.57 & 0.00 & 5.17 & 0.64 & 539 & - & 1129 \\
\hline Noheda 086 & 15.9 & 2.57 & 1.97 & 65.4 & 0.04 & 0.71 & 0.50 & 7.02 & 0.08 & 0.02 & 0.52 & 0.00 & 5.14 & 0.01 & 536 & - & - \\
\hline Noheda 092 & 17.1 & 0.40 & 1.95 & 65.4 & 0.03 & 1.25 & 0.52 & 5.27 & 0.08 & 0.10 & 0.43 & 0.01 & 4.90 & 2.34 & 520 & 613 & 1146 \\
\hline Noheda 093 & 14.6 & 1.51 & 1.69 & 64.7 & 0.08 & 0.88 & 0.51 & 6.01 & 0.07 & 0.04 & 0.45 & 0.02 & 9.23 & 0.03 & 541 & - & - \\
\hline Noheda 099 & 16.9 & 0.40 & 2.02 & 67.6 & 0.03 & 0.94 & 0.50 & 5.25 & 0.09 & 0.07 & 0.49 & 0.01 & 4.50 & 1.08 & 531 & 616 & 1122 \\
\hline Noheda 106 & 13.2 & 0.39 & 2.06 & 66.3 & 0.18 & 0.63 & 0.56 & 5.95 & 0.05 & 0.62 & 0.36 & 0.01 & 7.88 & 1.68 & 537 & 589 & 1155 \\
\hline
\end{tabular}


The heat treatment was carried out in a precisely controllable high temperature chamber (Anton Paar HTK 16) capable of reaching $1600{ }^{\circ} \mathrm{C}$ in air. Such high temperature chambers are a well-proven instrument for in situ X-ray diffraction studies. Employing the published instrumental setup and calibration [40] the X-ray diffraction patterns were acquired in the angular range of $20^{\circ}<2 \theta<35^{\circ}$ at the following nominal temperatures: $540,600,660,720,840,960,1080,1200{ }^{\circ} \mathrm{C}$ of the powdered glassy samples. Additional measurements were performed in the angular range of $14^{\circ}<2 \theta<32^{\circ}$. Temperatures were increased at $50^{\circ} \mathrm{C} / \mathrm{min}$ from 25 to 500 , then at $10^{\circ} \mathrm{C} / \mathrm{min}$ to the next value. After the calibration procedure reported in the literature, the correction of the nominal temperatures resulted in the following real temperatures: $450,500,550,600,700,800,900,1000{ }^{\circ} \mathrm{C}$ [40]. Due to the use of an $X^{\prime}$ Celerator detector, phase transformation events were recorded along the indicated $2 \theta$ range for $9.26 \mathrm{~min}$ per temperature. The powdered glass samples were singularly mixed with bi-distilled water and dropwise placed upon the Pt strip, which acted as thermocouple, heating element, and sample holder at the same time. After each sample was tested, the Pt strip was washed with HF solution to completely dissolve the glassy powder.

\section{Results and Discussion}

Of the 10 mosaic tesserae selected, five samples are natron-type glasses with typically low magnesia and potash levels $(<1.5 \mathrm{wt} . \%)$ and varying lead concentrations $(1<\mathrm{PbO}<2.5 \mathrm{wt} . \%)$, while five specimens have an excess of magnesia $(1.5<\mathrm{MgO}<4 \mathrm{wt} . \%)$ and low potash and phosphorus levels [37]. The concentration of antimony oxide in all the tesserae corresponds well with the presence of calcium antimonate crystals as the main pigment (for a detailed discussion on the chemical composition and the microstructure see [37]).

\subsection{Identification of Thermal Events}

Non-isothermal differential scanning calorimetry reveals different thermal events that appear as one, two or three endothermic peaks in the corresponding DSC curves (Figure 1, Figures S1-S10). All samples show a glass transition temperature $(\mathrm{Tg})$ and the corresponding peak [41] between 520 and $553^{\circ} \mathrm{C}$ that seems to correspond to a peak at $540{ }^{\circ} \mathrm{C}$ observed in some recently conducted glass model experiments [36]. Three samples (Noheda 76, 86, 93) display only this single endothermic peak, while six samples (Noheda 71, 77, 80, 92, 99 and 106) have an additional peak between 589 and $620^{\circ} \mathrm{C}$. This peak also represents a glass transition temperature, as already observed in Roman natron glasses opacified with calcium antimonate (see for comparison Figure 8 in [36]). These two $\mathrm{Tg}$ peaks correspond to two different glassy phases, one richer in silica, and the other one richer in network modifier cations. The peak at the higher temperature is usually attributed to the presence of a silica-rich phase in a phase-separated glass, which appears to be a relatively common phenomenon in silicate glasses, especially when the cooling rate is slow [40-42]. This phase separation can augment the perceived opalescence in the bulk glasses. Six samples (Noheda 77, 80, 84, 92, 99, 106) show a third endothermic event indicative of incipient melting. Melting, visible as a broad endothermic peak, occurs at different temperatures, ranging from 1122 to $1155^{\circ} \mathrm{C}$ (Figure 1). All the DSC present trends similar to those reported in Figure 1. It should be noted that our differential thermal analysis did not identify any crystallisation event, typically exothermic, in contrast to previous reports of experimental replica of natron glass opacified by $\mathrm{Ca}_{2} \mathrm{Sb}_{2} \mathrm{O}_{7}$ at temperature ranges from 100 to $1100{ }^{\circ} \mathrm{C}$ [36]. 


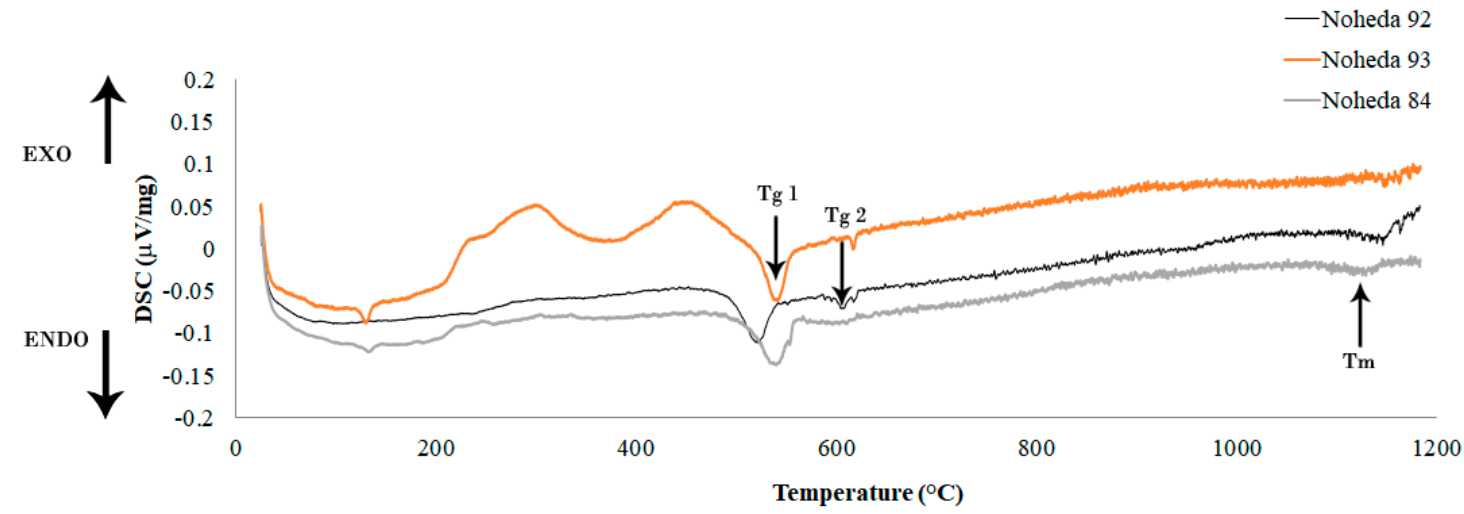

Figure 1. DSC curves of Noheda 93, 84 and 92 samples, showing one, two and three endothermic peaks, respectively. Sample 93: one peak, at $542{ }^{\circ} \mathrm{C}$. Sample 84: one peak at $539{ }^{\circ} \mathrm{C}$ and one peak at $1129^{\circ} \mathrm{C}$ (the tiny peak at $610^{\circ} \mathrm{C}$ is not significant for a thermal event, but is probably an effect of sample preparation). Sample 92: one peak at 520, second peak at 613 and third peak at $1146^{\circ} \mathrm{C}$. In the three samples, some peaks (around 120 and $300^{\circ} \mathrm{C}$ ) might be due to the loss of water absorbed by the powdered sample.

All samples with the highest lead concentrations $(\mathrm{PbO}>1 \%)$ show melting temperatures below $1200{ }^{\circ} \mathrm{C}$ (Table 1). This is in good agreement with the results obtained during experimental reproductions of glass melting in Roman-type wood-fired furnaces that reach a maximum temperature of approximately $1100{ }^{\circ} \mathrm{C}$ [43]. High lead concentrations do not have an effect on the position of the slope change at $300{ }^{\circ} \mathrm{C}$, but clearly shift the peak corresponding to the first thermal event from 553 to $520^{\circ} \mathrm{C}$, and the peak of the second thermal event from 620 to $589^{\circ} \mathrm{C}$. There appears to be an inverse correlation between the temperature of the first thermal event and the lead concentrations, which becomes more pronounced at higher concentrations ( $\mathrm{PbO}>2 \mathrm{wt} . \%$ ) (Figure 2). This result is in line with the workability interval measured for a raw glass from Pompeii $\left(685-892{ }^{\circ} \mathrm{C}\right)$ [38]. The curves from our non-isothermal differential thermal analysis overlap perfectly with those reported in the literature for laboratory replicas of Roman calcium antimonate-opacified glasses. However, since we recorded the curves across a broader temperature range (from $20^{\circ} \mathrm{C} / 293 \mathrm{~K}$ to $1200{ }^{\circ} \mathrm{C} / 1473 \mathrm{~K}$ ), our data additionally disclosed a change in the slope of the curve at $300^{\circ} \mathrm{C} / 573 \mathrm{~K}$, which was not clearly visible in previous experimental results [36].

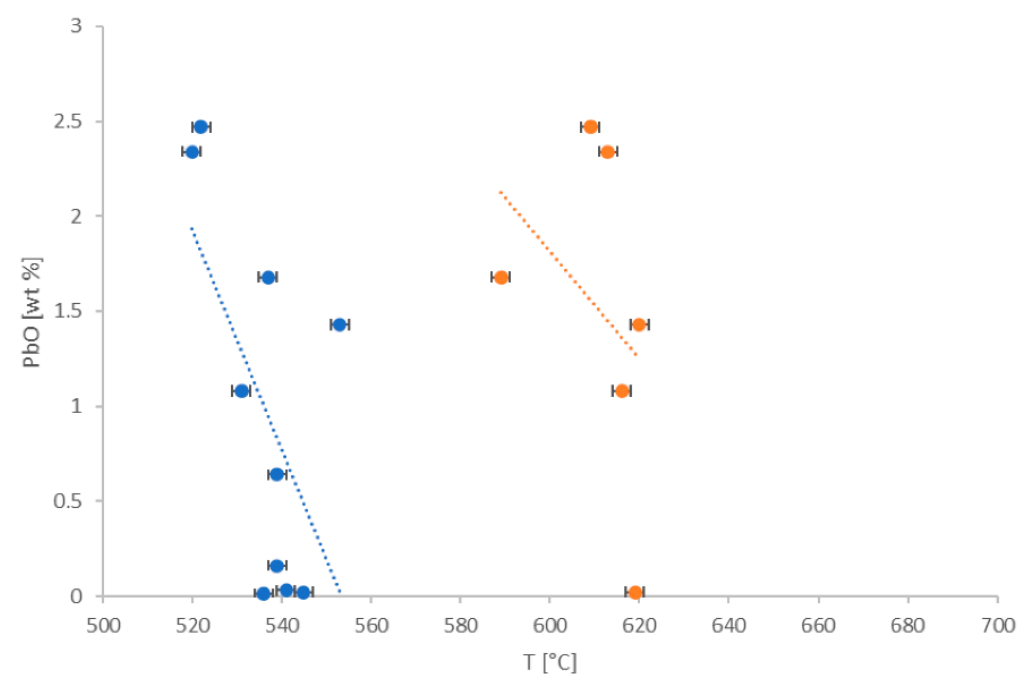

Figure 2. Correlation between the temperature and lead oxide concentration for the first (blue) and the second (orange) thermal event. 


\subsection{Linear Regression Model}

Multicomponent linear regression (MLR) was applied to the temperature of the first endothermic peak (Tg), for the five oxides reported in Table 2, together with the coefficients used for each oxide. MLR model shows good values for both R-squared and adjusted R-squared, equal to 0.9734 (also reported in Figure 3, under the equation of the line) and 0.9401, respectively. When the values of these two coefficients are close to the unit and are close to each other, the condition indicates that the parameters used for the fitting, in this case the oxide percentages, are appropriate and not redundant. In particular, we noticed that when $\mathrm{SiO}_{2}$ and/or $\mathrm{Na}_{2} \mathrm{O}$ were introduced into the model, the two values for R-squared and adjusted R-squared diverge more, indicating an excess of parameters to describe the thermal behavior, at least in the percentage ranges considered. As the conclusions of this statistical study, we can say that the five oxides listed in Table 2 are the minimum, yet sufficient, number of chemical variables able to justify the trend in the thermal behavior. Please notice that, even though each single oxide has its own variability in the chemical composition (see Table 1), a high concentration in the glass formula is not necessarily relevant to the statistical model. This is the case for silica, where, statistically speaking, the compositional variations have a very mild effect on the temperature of the glass transition.

Table 2. Coefficients adopted in the MLR for the five oxides that provided the better data fitting (See Equation (1) and Figure 3).

\begin{tabular}{ccc}
\hline & Coefficient & Standard Error \\
\hline $\mathrm{MgO}$ & 4.9168 & \pm 1.5874 \\
\hline $\mathrm{Al}_{2} \mathrm{O}_{3}$ & 52.0224 & \pm 7.8020 \\
\hline $\mathrm{CaO}$ & -6.4054 & \pm 2.9516 \\
\hline $\mathrm{Sb}_{2} \mathrm{O}_{3}$ & 3.6050 & \pm 0.6639 \\
\hline $\mathrm{PbO}$ & -6.3829 & \pm 1.3941 \\
\hline
\end{tabular}

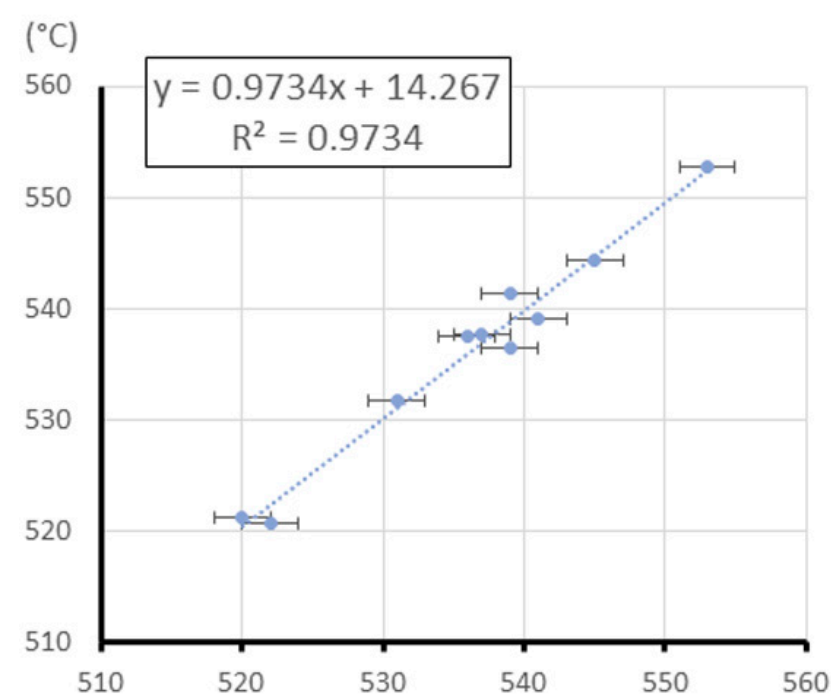

Figure 3. Correlation between the first $\mathrm{Tg}$ temperature for the DSC curves $(X)$ and the value predicted by the MLR model (Y) adopting the coefficients presented in Table 2. Error bar is reported only for experimental values.

Concerning the coefficient assigned to each oxide by the model (Table 2), the higher the absolute value, the more significant the coefficient is for the model. The positive sign of the coefficient indicates that the increase in temperature is coupled with the increase of oxide concentration, while the negative sign indicates the opposite. Alumina, magnesium and antimony oxides evidently increase the $\mathrm{Tg}$ 
temperatures, whereas lead and calcium oxide have the opposite effect (Table 2). This trend partially contradicts what is documented in the literature [44,45], because antimony in silicate glass is said to lower $\mathrm{Tg}$, and calcium is supposed to increase the $\mathrm{Tg}$. However, given that the glasses are opaque, it can be assumed that part of the calcium and antimony oxides are in the crystalline phases. This may explain the inversion of their typical behaviour in silicate glass. In fact, the presence of a crystalline phase impedes the viscous flow with a slight increase in $\mathrm{Tg}$.

Thus, the most relevant oxides in the glassy phase are alumina and lead oxide, characterised respectively by a positive and a negative coefficient. Their concentration in the glass is very low $(<3 \mathrm{wt} . \%)$, but their effect on the transition glass temperature is highly significant. While alumina is a contaminant of the silicate raw materials used for the preparation of the glass batch during glass-making, lead was added only during the secondary process of opacification.

The MLR model, adopting the coefficients presented in Table 2, propose the following equation:

$$
\mathrm{T}_{\mathrm{g}}=449.05+4.9168 \cdot \mathrm{MgO}+52.0224 \cdot \mathrm{Al}_{2} \mathrm{O}_{3}-6.4054 \cdot \mathrm{CaO}+3.6050 \cdot \mathrm{Sb}_{2} \mathrm{O}_{3}-6.3829 \cdot \mathrm{PbO}
$$

where $\mathrm{Tg}$ is the temperature of the first endothermic peak and $\mathrm{MgO}, \mathrm{Al}_{2} \mathrm{O}_{3}, \mathrm{CaO}, \mathrm{Sb}_{2} \mathrm{O}_{3}$ and $\mathrm{PbO}$ the $\mathrm{wt} \%$ of the oxides. This model predicts the $\mathrm{Tg}$ values with an incredibly good correlation of $\mathrm{R}^{2}=$ 0.9734 , accompanied by a slope of almost $45^{\circ}$, slope value $=0.9734$ (Figure 3 ). The regression model fits well with the experimental $\mathrm{Tg}$ values since the fitted values are not systematically too high or low anywhere in the observation space. Additionally, the statistical significance of the estimated parameters is extremely good, evaluated by the test $\mathrm{F}$, that is very low $(\mathrm{F}=0.003014)$. We can, therefore, state that the addition of the lead oxide lowers the glass transition temperature, hence the glass workability.

\subsection{Identification of Crystalline Phases}

The X-ray diffraction analyses identify two main crystalline phases $\left(\mathrm{CaSb}_{2} \mathrm{O}_{6}\right.$ and $\left.\mathrm{Ca}_{2} \mathrm{Sb}_{2} \mathrm{O}_{7}\right)$ and two different diffraction patterns, represented by samples Noheda 92 and 93 (Figure 4). Sample 92 is a low-magnesium, high-lead glass, while sample 93 is high in magnesium and low in lead (Table 1). The two samples are characterized by one and two peaks in the XRD pattern, respectively, that show similar thermal behaviors in the $450-500{ }^{\circ} \mathrm{C}$ range. In both samples the XRD patterns remain practically unchanged (Figure 4), thus no crystallization processes can be identified up to $550^{\circ} \mathrm{C}$, in accordance with the absence of an exothermic crystallisation process in the DSC curve in this temperature interval. For both glass compositions, the high temperature measurements established the thermal stability of the $\mathrm{CaSb}_{2} \mathrm{O}_{6}$ and $\mathrm{Ca}_{2} \mathrm{Sb}_{2} \mathrm{O}_{7}$ crystalline phases in the temperature range of $25-550{ }^{\circ} \mathrm{C}$.

a)

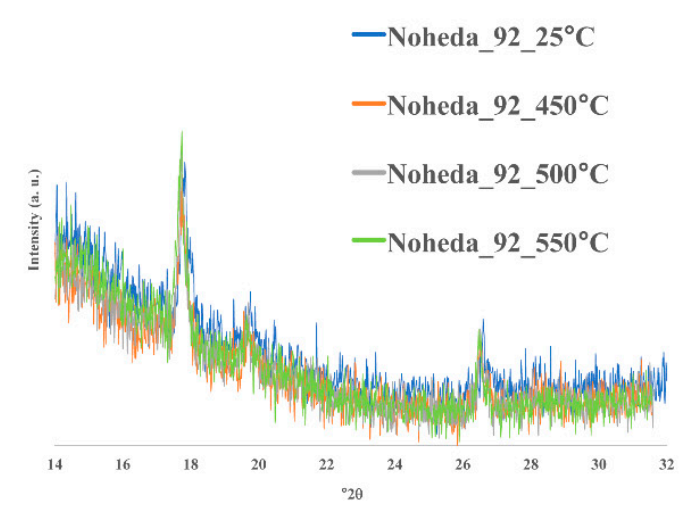

b)

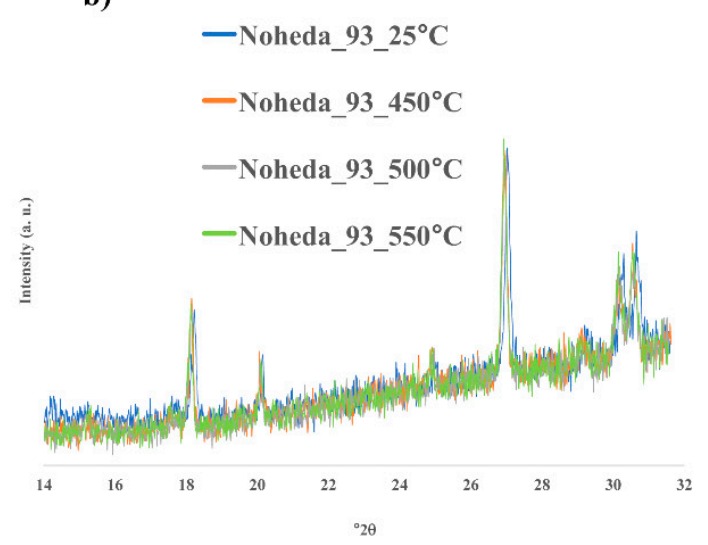

Figure 4. High temperature in situ XRD patterns collected on samples Noheda 92 (a) and Noheda 93 (b) during heating, in the temperature range $25-550{ }^{\circ} \mathrm{C}$. 
High-temperature XRD between 600 and $1000{ }^{\circ} \mathrm{C}\left(14-32{ }^{\circ} 2 \theta\right)$ confirmed that sample Noheda 92 contains only the hexagonal crystalline phase $\left(\mathrm{CaSb}_{2} \mathrm{O}_{6}\right)$ (Figure 5a), while in sample Noheda 93 orthorhombic crystals $\left(\mathrm{Ca}_{2} \mathrm{Sb}_{2} \mathrm{O}_{7}\right)$ were also detected (Figure $5 \mathrm{~b}$ ). As the temperature approaches approximately $700^{\circ} \mathrm{C}$, the diffraction peak centred at about $18^{\circ}$ in $2 \theta$ increases in intensity in both samples. This phenomenon is due to the growth of a new additional crystal, identified as one of the forms of $\mathrm{SiO}_{2}$. (ICSD file no: 01-082-1576, Crystal System: Anorthic, Space Group: P1, Space group number: [46]). Since only endothermic peaks occur above $600{ }^{\circ} \mathrm{C}$ in the DSC curves, it is likely that the formation of the new phase was due to the slow heating schedule adopted for the XRD in situ high temperature measurements. Both the $\mathrm{CaSb}_{2} \mathrm{O}_{6}$ and $\mathrm{Ca}_{2} \mathrm{Sb}_{2} \mathrm{O}_{7}$ crystalline phases proved to be stable up to a temperature of $1000{ }^{\circ} \mathrm{C}$ (magnification detail, Figure 5b). This result supports the hypothesis that the opacifier-here calcium antimonate $\left(\mathrm{CaSb}_{2} \mathrm{O}_{6}\right)$-was formed during the cooling phase of the glass melt [14]. The XRD patterns of both samples re-collected at the same temperatures during the cooling phase, from 1000 to $25^{\circ} \mathrm{C}$, showed no further changes compared to the patterns obtained during the first heating step, indicating that the two opaque glasses were not submitted to any further reheating cycle, such as annealing processes at temperatures higher than $700-800{ }^{\circ} \mathrm{C}$. The crystalline form of $\mathrm{SiO}_{2}$ was irreversibly developed during heating, since it was equally observed during cooling.

a)

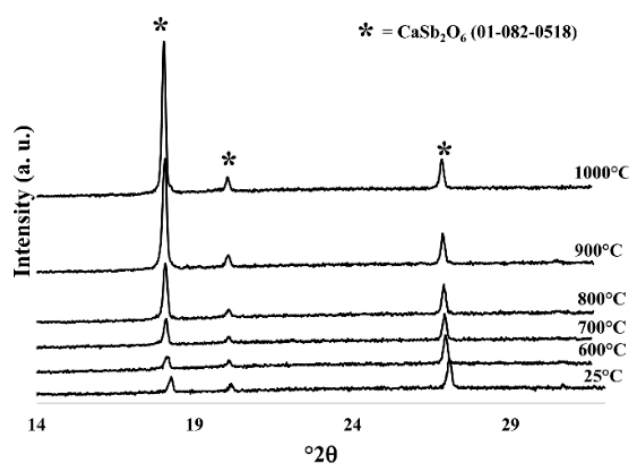

b)

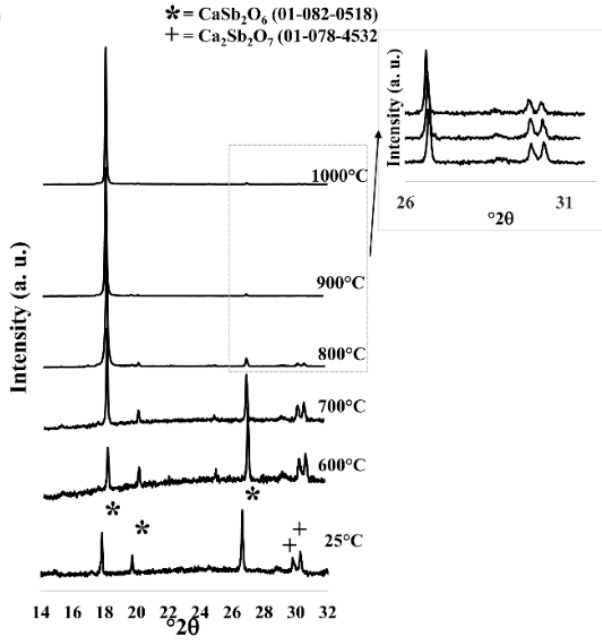

Figure 5. XRD pattern for the samples 092 (a) and 093 (b) at the most significant temperatures.

The XRD patterns generally show very low intensities of the crystalline phases, indicating that the major phase is the amorphous glass matrix. The principal crystalline phase is $\mathrm{CaSb}_{2} \mathrm{O}_{6}$, with only small quantities of $\mathrm{Ca}_{2} \mathrm{Sb}_{2} \mathrm{O}_{7}$ crystals in some of the high magnesia samples. There is no correlation between the presence of the two crystalline phases and lead concentration. In contrast, high magnesia levels appear to have a favourable impact on the formation of calcium antimonate and, more specifically, on the precipitation of the orthorhombic form $\left(\mathrm{Ca}_{2} \mathrm{Sb}_{2} \mathrm{O}_{7}\right) \cdot \mathrm{Mg}^{2+}$ is a glass modifier with high field strength $[47,48]$, and the presence of $\mathrm{MgO}$ appears to contribute to the segregation of $\mathrm{CaO}$, which in turn may promote the formation of $\mathrm{Ca}_{2} \mathrm{Sb}_{2} \mathrm{O}_{7}$, according to the chemical reaction $\mathrm{CaSb}_{2} \mathrm{O}_{6}+\mathrm{CaO}=$ $\mathrm{Ca}_{2} \mathrm{Sb}_{2} \mathrm{O}_{7}$. This hypothesis should be validated by further investigations. The absence of a crystalline silica-phase at room temperature indicates that the glass tesserae were not subjected to secondary thermal treatment that would otherwise have fostered the growth of a $\mathrm{SiO}_{2}$ phase, as observed from about $700{ }^{\circ} \mathrm{C}$ in both samples Noheda 92 and 93. The thermal stability of both $\mathrm{Ca}_{2} \mathrm{Sb}_{2} \mathrm{O}_{7}$ and $\mathrm{CaSb}_{2} \mathrm{O}_{6}$ crystalline forms during heating up to $1000{ }^{\circ} \mathrm{C}$ and cooling confirms that the crystals precipitated from the fluid glass during the cooling phase, starting at temperatures lower than $100{ }^{\circ} \mathrm{C}$ (Figs. 1, 3). The presence of an appreciable amount of lead oxide dissolved in the glass matrix ( $\mathrm{PbO}>2 \mathrm{wt} . \%)$ has shown to favour all thermal events by reducing the peak temperature by about $20{ }^{\circ} \mathrm{C}$ (Figure 2). 


\section{Conclusions}

The present investigation has shown that lead has no direct influence on the synthesis of either form of calcium antimonate $\left(\mathrm{CaSb}_{2} \mathrm{O}_{6}\right.$ or $\left.\mathrm{Ca}_{2} \mathrm{Sb}_{2} \mathrm{O}_{7}\right)$. However, even low concentrations of lead oxide in the glass matrix lowers the temperature of all the thermal events during the process of opacification. Considering the formation of the $\mathrm{SiO}_{2}$ phase above $700{ }^{\circ} \mathrm{C}$, we conclude that the working temperature for glass opacification was likely significantly lower than the $1100{ }^{\circ} \mathrm{C}$ estimated in the literature for the precipitation of the calcium antimonate crystals. A long thermal cycle above this temperature would have induced the separation of the silica phase, which is absent in the mosaic tesserae. Glass opacification could have been thus practiced at the same temperatures needed for glass working. It can be assumed that the elevated concentrations of lead oxide had an impact on the economy of the opacification process. The introduction of some lead, most likely as lead oxide, to the glass batch allows the glass artisans to save fuel and to shorten the times of the production process. It is, therefore, conceivable that lead oxide was deliberately added, or that raw materials containing lead were intentionally selected for this purpose.

Supplementary Materials: The following are available online at http://www.mdpi.com/2571-9408/3/2/32/s1.

Author Contributions: Conceptualization, C.B., C.L. and N.S.; Data curation, C.B., C.L., R.R. and N.S.; Formal analysis, C.L., R.R., M.R. and N.S.; Funding acquisition, N.S.; Methodology, C.B., C.L., M.R. and N.S.; Visualization, C.B., C.L., R.R., N.S., M.R., M.Á.V.T.; Writing - original draft, C.B., C.L., R.R., M.R. and N.S.; Writing - review \& editing, C.B., C.L., R.R., M.R. and N.S. The archaeological material was provided by M.Á.V.T. All authors have read and agreed to the published version of the manuscript.

Funding: This project has received funding from the European Research Council (ERC) under the European Union's Horizon 2020 research and innovation programme (GlassRoutesfigure, grant agreement No. 647315 to NS).

Acknowledgments: We wish to thank Cecilia Rossi and Massimo Tonelli (CIGS-Università di Modena e Reggio Emilia) for their assistance during the XRD analyses and Paola Miselli (Dipartimento di Ingegneria "Enzo Ferrari", Università di Modena e Reggio Emilia) for her assistance during the DSC analyses.

Conflicts of Interest: The authors declare no conflict of interest. The funding organisations had no influence in the study design, data collection and analysis, decision to publish, or preparation of the manuscript.

\section{References}

1. Shortland, A.J. The use and origin of antimonate colorants in early Egyptian glass. Archaeometry 2002, 44, 517-530. [CrossRef]

2. Tite, M.; Shortland, A.; Paynter, S. The beginnings of vitreous materials in the Near East and Egypt. Acc. Chem. Res. 2002, 35, 585-593. [CrossRef] [PubMed]

3. Turner, W.E.S.; Rooksby, H.P. A study of the opalising agents in ancient opal glasses throughout three thousand four hundred years. Glastech. Ber. 1959, 8, 17-28.

4. Rutten, F.J.M.; Briggs, D.; Henderson, J.; Roe, M.J. The application of time-of-flight secondary ion mass spectrometry (Tof-SIMS) to the characterization of opaque ancient glasses. Archaeometry 2009, 51, 966-986. [CrossRef]

5. Duckworth, C.N.; Henderson, J.; Rutten, F.J.M.; Nikita, K. Opacifiers in Late Bronze Age glasses: The use of ToF-SIMS to identify raw ingredients and production techniques. J. Archaeol. Sci. 2012, 39, 2143-2152. [CrossRef]

6. Licenziati, F.; Calligaro, T. Study of mosaic glass tesserae from Delos, Greece using a combination of portable $\mu$-Raman and X-ray fluorescence spectrometry. J. Archaeol. Sci. Rep. 2016, 7, 640-649. [CrossRef]

7. Venclová, N.; Kř́žová, Š.; Dillingerová, V.; Vaculovič, T. Hellenistic cast monochrome glass vessels from Staré Hradisko, 2nd-1st cent. BCE. J. Archaeol. Sci. Rep. 2018, 22, 540-549. [CrossRef]

8. Boschetti, C.; Henderson, J.; Evans, J.; Leonelli, C. Mosaic tesserae from Italy and the production of Mediterranean coloured glass (4rd century BCE-4th century CE). Part I: Chemical composition and technology. J. Archaeol. Sci. Rep. 2016, 7, 303-311. [CrossRef]

9. Boschetti, C.; Mantovani, V.; Leonelli, C. Glass coloring and recycling in Late Antiquity: A new case study from Aquileia (Italy). J. Glass Stud. 2016, 58, 69-86. 
10. Gliozzo, E.; Santagostino Barbone, A.; Turchiano, M.; Memmi, I.; Volpe, G. The coloured tesserae decorating the vaults of the Faragola balneum (Ascoli Satriano, Foggia, Southern Italy). Archaeometry 2012, 54, 311-331. [CrossRef]

11. Henderson, J. The raw materials of early glass production. Oxf. J. Archaeol. 1985, 4, 267-291. [CrossRef]

12. Lahlil, S.; Biron, I.; Cotte, M.; Susini, J. New insight on the in situ crystallization of calcium antimonate opacified glass during the Roman period. Appl. Phys. A Mater. Sci. Process. 2010, 100, 683-692. [CrossRef]

13. Lahlil, S.; Biron, I.; Cotte, M.; Susini, J.; Menguy, N. Synthesis of calcium antimonate nano-crystals by the 18th dynasty Egyptian glassmakers. Appl. Phys. A Mater. Sci. Process. 2010, 98, 1-8. [CrossRef]

14. Lahlil, S.; Biron, I.; Galoisy, L.; Morin, G. Rediscovering ancient glass technologies through the examination of opacifier crystals. Appl. Phys. A Mater. Sci. Process. 2008, 92, 109-116. [CrossRef]

15. Maltoni, S.; Silvestri, A.; Marcante, A.; Molin, G. The transition from Roman to Late Antique glass: New insights from the Domus of Tito Macro in Aquileia (Italy). J. Archaeol. Sci. 2016, 73, 1-16. [CrossRef]

16. Neri, E.; Verita, M.; Conventi, A. Glass mosaic tesserae from the 5th-6th century baptistery of San Giovanni alle Fonti, Milan, Italy. Analytical investigations. In New Light on Old Glass: Recent Research on Byzantine Mosaics and Glass; Entwistle, C., James, L., Eds.; British Museum Press: London, UK, 2013; pp. 1-10.

17. Schibille, N.; Neri, E.; Ebanista, C.; Ammar, M.R.; Bisconti, F. Something old, something new: The late antique mosaics from the catacomb of San Gennaro (Naples). J. Archaeol. Sci. Rep. 2018, 20, 411-422. [CrossRef]

18. Silvestri, A.; Tonietto, S.; Molin, G.; Guerriero, P. The palaeo-Christian glass mosaic of St. Prosdocimus (Padova, Italy): Archaeometric characterisation of tesserae with antimony-or phosphorus-based opacifiers. J. Archaeol. Sci. 2012, 39, 2177-2190. [CrossRef]

19. Wypyski, M.T.; Becker, L. Glassmaking technology at Antioch: Evidence from the Atrium House Triclinium and later mosaics. In The Arts of Antioch-Art Historical and Scientific Approaches to Roman Mosaics; Becker, L., Kondoleon, C., Eds.; Worcester Art Museum: Worcester, MA, USA, 2005; pp. 115-175.

20. Gliozzo, E.; Barbone, A.S.; D’Acapito, F.; Turchiano, M.; Memmi, I.T.; Volpe, G. The Sectilia Panels of Faragola (Ascoli Satriano, Southern Italy): A Multi-Analytical Study of the Green, Marbled (Green and Yellow), Blue and Blackish Glass Slabs. Archaeometry 2010, 52, 389-415. [CrossRef]

21. Tesser, E.; Verità, M.; Lazzarini, L.; Falcone, R.; Saguì, L.; Antonelli, F. Glass in imitation of exotic marbles: An analytical investigation of $2^{\text {nd }}$-century AD Roman sectilia from the Gorga collection. J. Cult. Herit. 2019. [CrossRef]

22. Tite, M.; Pradell, T.; Shortland, A. Discovery, production and use of tin-based opacifiers in glasses, enamels and glazes from the late iron age onwards: A reassessment. Archaeometry 2008, 50, 67-84. [CrossRef]

23. Uboldi, M.; Verita, M. Scientific analyses of glasses from Late Antique and Early Medieval archeological sites in Northern Italy. J. Glass Stud. 2003, 45, 115-137.

24. Neri, E.; Jackson, M.; O’Hea, M.; Gregory, T.; Blet-Lemarquand, M.; Schibille, N. Analyses of glass tesserae from Kilise Tepe: New insights into an early Byzantine production technology. J. Archaeol. Sci. Rep. 2017, 11, 600-612. [CrossRef]

25. Schibille, N.; Gratuze, B.; Ollivier, E.; Blondeau, É. Chronology of early Islamic glass compositions from Egypt. J. Archaeol. Sci. 2019, 104, 10-18. [CrossRef]

26. Tite, M.; Watson, O.; Pradell, T.; Matin, M.; Molina, G.; Domoney, K.; Bouquillon, A. Revisiting the beginnings of tin-opacified Islamic glazes. J. Archaeol. Sci. 2015, 57, 80-91. [CrossRef]

27. Moretti, C.; Salerno, C.S.; Ferroni, S.T. Ricette Vetrarie Muranesi: Gasparo Brunoro e il Manoscritto di Danzica; Nardini Florence: Florence, Italy, 2004.

28. Wainwright, I.N.; Taylor, J.M.; Harley, R.D. Lead antimonate yellow. In Artists' Pigments: A Handbook of Their History and Characteristics; National Gallery of Art; Cambridge University Press: Washington DC, USA, 1986; Volume 1, pp. 219-254.

29. Freestone, I.C. Laboratory studies of the Portland Vase. J. Glass Stud. 1990, 32, 103-107.

30. Freestone, I.C.; Stapleton, C. Composition technology and production of coloured glasses from Roman mosaic vessels. In Glass of the Roman World; Bayley, J., Freestone, I.C., Jackson, C., Eds.; Oxbow: Oxford, UK, 2015; pp. 61-76.

31. Gedzevičiūtè, V.; Welter, N.; Schüssler, U.; Weiss, C. Chemical composition and colouring agents of Roman mosaic and millefiori glass, studied by electron microprobe analysis and Raman microspectroscopy. Archaeol. Anthropol. Sci. 2009, 1, 15-29. [CrossRef] 
32. Paynter, S.; Jackson, C. Clarity and brilliance: Antimony in colourless natron glass explored using Roman glass found in Britain. Archaeol. Anthropol. Sci. 2018, 1-19. [CrossRef]

33. Roberts, P.; Gudenrath, W.; Tatton-Brown, V.; Whitehouse, D. Roman Cameo Glass in the British Museum; British Museum Publications Limited: London, UK, 2010.

34. Sablerolles, Y.; Henderson, J.; Dijkman, W. Early medieval glass bead-making in Maastricht (Jodenstraat 30), The Netherlands. An archaeological and scientific investigation. In Perlen: Archäologie, Techniken, Analysen; Akten des Internationalen Perlensymposiums in Mannheim vom 11. bis 14. November 1994; von Freeden, U., Wiczorek, A., Eds.; Habelt: Bonn, Germany, 1997; pp. 225-226, 293-314.

35. Verità, M. Perle vitree dalle necropoli longobarde in Italia. Natura dei materiali e tecniche di lavorazione. In Archeologia Medievale a Trezzo Sull'Adda. Il Sepolcreto Longobardo e l'Oratorio di San Martino. Le chiese di Santo Stefano e San Michele in Sallianense; Contributi di Archeologia; V\&P Vita e Pensiero: Milano, Italy, 2012; pp. 355-378.

36. Drünert, F.; Palamara, E.; Zacharias, N.; Wondraczek, L.; Möncke, D. Ancient Roman nano-technology: Insight into the manufacture of mosaic tesserae opacified by calcium antimonate. J. Eur. Ceram. Soc. 2018, 38, 4799-4805. [CrossRef]

37. Schibille, N.; Boschetti, C.; Valero Tévar, M.Á.; De Juan Ares, J.; Veron, E. The colour palette of the mosaics in the Roman villa of Noheda (Spain). Minerals 2020, 10, 272. [CrossRef]

38. Montanari, F.; Miselli, P.; Leonelli, C.; Boschetti, C.; Henderson, J.; Baraldi, P. Calibration and use of the heating microscope for indirect evaluation of the viscosity and meltability of archeological glasses. Int. J. Appl. Glass Sci. 2014, 5, 161-177. [CrossRef]

39. Jobson, J.D. Applied Multivariate Data Analysis Volume I: Regression and Experimental Design; Springer: Berlin/Heidelberg, Germany, 1991.

40. Gualtieri, A.F.; Andreozzi, G.B.; Giacobbe, C.; Lusvardi, G.; Viti, C. Structural and spectroscopic characterization of anorthite synthesized from secondary raw materials. Periodico di Mineralogia 2011, 80, 231-245. [CrossRef]

41. Zheng, Q.; Zhang, Y.; Montazerian, M.; Gulbiten, O.; Mauro, J.C.; Zanotto, E.D.; Yue, Y. Understanding Glass through Differential Scanning Calorimetry. Chem. Rev. 2019, 119, 7848-7939. [CrossRef] [PubMed]

42. Lara, C.; Pascual, M.; Duran, A. Glass-forming ability, sinterability and thermal properties in the systems $\mathrm{RO}-\mathrm{BaO}-\mathrm{SiO} 2$ (R = Mg, Zn). J. Non-Cryst. Solids 2004, 348, 149-155. [CrossRef]

43. Wiesenberg, F. Experimentelle Archäologie: Römische Glasöfen: Rekonstruktion und Betrieb einer Glashütte nach römischem Vorbild in der Villa Borg: “Borg Furnace Project 2013". 2014. Available online: http://openarchaeology.info/bibliography/experimentelle-archaologie-romische-glasofenrekonstruktion-und-betrieb-einer-glashutte (accessed on 25 June 2020).

44. Shelby, J.E. Introduction to Glass Science and Technology; Royal Society of Chemistry: Cambridge, UK, 2005.

45. Mee, M.; Davies, B.C.; Orman, R.G.; Thomas, M.F.; Holland, D. Antimony and silicon environments in antimony silicate glasses. J. Solid State Chem. 2010, 183, 1925-1934. [CrossRef]

46. Nakagawa, K.; Izumitani, T. Metastable phase separation and crystallization of Li2O $\Lambda$ Al2O3 $\Lambda \mathrm{SiO} 3$ glasses: Determination of miscibility gap from the lattice parameters of precipitated $\beta$-quartz solid solution. J. Non-Cryst. Solids 1972, 7, 168-180. [CrossRef]

47. Boisen, M.B., Jr.; Gibbs, G.V.; Bukowinski, M.S.T. Framework silica structures generated using simulated annealing with a potential energy function based on an H 6 Si 2 O 7 molecule. Phys. Chem. Miner. 1994, 21, 269-284. [CrossRef]

48. Vogel, W. Glass Chemistry; Springer Science \& Business Media: Berlin/Heidelberg, Germany, 1994.

(C) 2020 by the authors. Licensee MDPI, Basel, Switzerland. This article is an open access article distributed under the terms and conditions of the Creative Commons Attribution (CC BY) license (http://creativecommons.org/licenses/by/4.0/). 